\title{
Risk Assessment of Flood Disaster in Linyi City Based on GIS
}

\author{
Zheng Huang ${ }^{1, *}$ \\ ${ }^{1}$ School of Geomatics and Urban Spatial Informatics, Beijing University of Civil Engineering and Architecture, Beijing, China
}

\begin{abstract}
With the continuous acceleration of the urbanization process, the flood problem seriously affects the economic and social development of the city and the daily life of citizens. Therefore, taking Linyi City as an example, the flood disaster risk assessment is carried out, the Linyi City flood disaster assessment index system is constructed, and the methods of mathematical statistics, analytic hierarchy process and spatial overlay analysis are used to calculate the environmental sensitivity of Linyi City flood disasters with the help of GIS technology. , Risk of hazard factors, vulnerability of hazard-bearing bodies, disaster prevention and mitigation capabilities. The research results show that the hazard levels of flood disasters are increasing from west to east, and high-risk areas are distributed in Feixian and Junan counties; sensitivity is affected by topography and gradually increases from north to south; Lanshan District, Luozhuang District, etc. The city center is highly vulnerable due to its significant population and economic status, and has strong disaster prevention and mitigation capabilities.
\end{abstract}

\section{Introduction}

Flood disaster is a kind of severe natural disaster with strong suddenness, high frequency and wide distribution area. In our country, about $50 \%$ of the population and $70 \%$ of the property are distributed in the flood threat area [1]. In order to effectively achieve the purpose of flood fighting and disaster relief, to accurately analyze and evaluate the possibility of flood disasters and possible losses, and to better formulate disaster prevention and mitigation countermeasures and measures, flood disaster risk research is particularly important [2-4]. In recent years, a large number of scholars at home and abroad have carried out a lot of research work on flood disaster risk assessment and zoning [5-8] and established a set of more mature flood disaster risk assessment methods. Huang Guoru et al. [9] summarized the application status, scope of application, advantages and disadvantages of the four flood risk assessment methods; Wu Shuqi et al. [10-11] established a flood disaster risk assessment model in Zhejiang Province at the county scale for comprehensive evaluation and analysis. Comprehensive management provides a certain reference;

This paper takes Linyi City as the research object, uses existing data, and comprehensively considers the four evaluation indicators of flood hazard hazard factors, hazard environment sensitivity, hazard-bearing body vulnerability, and disaster prevention and mitigation capabilities, and uses GIS spatial analysis The technology spatializes each index factor, and combines the analytic hierarchy process to determine the weight of each influencing factor, and conducts the flood disaster risk assessment of Linyi City. This research can provide methodological basis for the flood disaster early warning and disaster prevention and reduction decision-making in Linyi City.

\section{Overview of the study area and data sources and processing}

\subsection{Survey of the study area}

Linyi City is located between $34^{\circ} 22^{\prime} \sim 36^{\circ} 13^{\prime}$ north latitude and $117^{\circ} 24^{\prime} \sim 119^{\circ} 11^{\prime}$ east longitude. It is located in the southeast of Shandong Province, close to the Yellow Sea, with a total area of 17,191.2 square kilometers and a permanent population of 10.667 million. The urbanization rate is $52.75 \%$. It has jurisdiction over 3 districts, 9 counties, and 3 development zones. It is the largest and most populous city in Shandong Province. The administrative division map is shown in Figure 1. The topography is centered on the $\mathrm{Yi}$ and Shu Rivers, surrounded by mountains in the west, north and east, forming a fan-shaped alluvial plain to the south. The area ratio of mountains, hills, and plains is $2: 4: 4$; Linyi has a temperate monsoon climate, with obvious seasonal precipitation. The precipitation is concentrated in summer, with the most precipitation in July. In recent years, Linyi City has been severely affected by flooding disasters. In the summer of 2019, many areas in Linyi City were affected. Hedong District and Yishui County were flooded. The city's affected population was 358,600 , and the affected area of crops was 5,9257.3 hectares.

*Corresponding author: 2108521519023@stu.bucea.edu.cn 


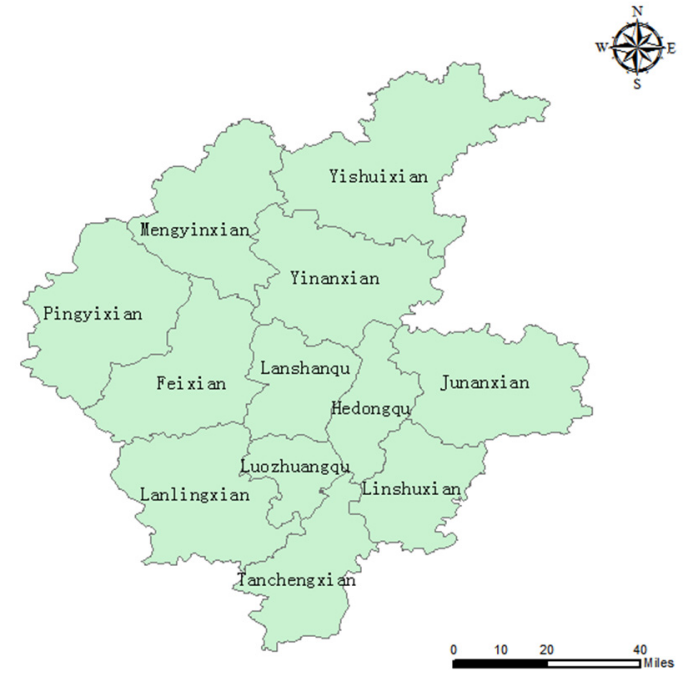

Figure 1. Administrative District Map of Linyi City

\subsection{Data source and processing}

The data used in this paper mainly include the daily precipitation records of 9 meteorological stations in Linyi City from 2010 to 2019, which come from the China Meteorological Data Network. The DEM data of Linyi City comes from the geospatial data cloud, and the GDP per capita and GDP per area come from the Linyi City Statistical Yearbook.

Flood disaster risk assessment indicators have different dimensions. Because of the need to superimpose the raster data of each indicator, in order to eliminate the differences caused by the different data dimensions and maintain reasonableness, it is necessary to standardize the evaluation index data, that is, data quantification processing. In this paper, formula (1) is used to normalize each index into a calculable non-vector index between 0 and 1:

$$
X_{i}^{\prime}=\frac{X_{i}-X_{\text {imin }}}{X_{\text {imax }}-X_{\text {imin }}}
$$

Where $X^{\prime}{ }_{i}$ is the normalized value of the $\mathrm{i}$-th index, $X_{i}$ is the i-th index value, and $X_{\text {imin }}$ and $X_{\text {imax }}$ are the minimum and maximum values of the $i$-th index, respectively.

\section{Research method}

\subsection{Evaluation index system construction}

In the selection of indicators for flood disaster risk assessment in Linyi City, not only the objectivity and availability of each indicator data must be considered, but also the indicators selected must be able to reflect the actual situation of flood disaster risk in the region. The risk of hazard factors mainly depends on meteorological factors and underlying surface factors. In this paper, two indicators of rainfall intensity and rainfall frequency are selected as hazard factors. The sensitivity of hazardpregnant environment mainly depends on the external environment. This study uses ground elevation and slope to determine the hazard-pregnant environment sensitivity index. The vulnerability of disaster-bearing bodies mainly depends on social and economic factors such as population and economy. This paper selects the average population and GDP per area to evaluate the vulnerability. Disaster prevention and mitigation capabilities mainly depend on pre-disaster protection and post-disaster response. This study uses per capita GDP to evaluate the disaster prevention and mitigation capabilities of the study area.

\subsection{Index weight determination}

The Analytic Hierarchy Process (AHP) is often used to assign values to various indicators and factors, and then to make decisions on fuzzy and complex problems. The main steps are: (1) construct the judgment matrix; (2) calculate the index weight; (3)check the consistency. This article uses analytic hierarchy process and expert scoring method to analyze the relationship between the factors in the system and establish the hierarchical structure of the system. Experts are asked to score the factors in pairs and compare the elements of the same level with respect to a certain criterion in the previous level. The importance is compared in pairs, and a pairwise comparison matrix (judgment matrix) is constructed. Calculate the relative weight of the compared element to the criterion from the judgment matrix, and conduct a consistency test $(\mathrm{CR}<0.1)$, and finally get the comprehensive weight, and calculate the risk index (Table 1).

Table 1. Flood risk assessment indicators and their weights in

\begin{tabular}{|c|c|c|c|c|}
\hline \multicolumn{5}{|c|}{ Linyi. } \\
\hline Target layer & $\begin{array}{l}\text { Criterion } \\
\text { layer }\end{array}$ & $\begin{array}{l}\text { Criterion- } \\
\text { level } \\
\text { weight }\end{array}$ & Index layer & $\begin{array}{l}\text { Index } \\
\text { layer } \\
\text { weight }\end{array}$ \\
\hline \multirow{10}{*}{$\begin{array}{l}\text { Flood } \\
\text { disaster risk } \\
\text { assessment }\end{array}$} & \multirow{5}{*}{ Hazard risk } & \multirow{5}{*}{0.489} & $\begin{array}{l}\text { First-degree } \\
\text { flood } \\
\text { frequency }\end{array}$ & 0.06 \\
\hline & & & $\begin{array}{l}\text { Secondary } \\
\text { flood } \\
\text { frequency }\end{array}$ & 0.08 \\
\hline & & & $\begin{array}{l}\text { Three-level } \\
\text { flood } \\
\text { frequency }\end{array}$ & 0.15 \\
\hline & & & $\begin{array}{l}\text { Four-level } \\
\text { flood } \\
\text { frequency }\end{array}$ & 0.25 \\
\hline & & & $\begin{array}{l}\text { Five-level } \\
\text { flood } \\
\text { frequency }\end{array}$ & 0.46 \\
\hline & \multirow{2}{*}{$\begin{array}{l}\text { Disaster } \\
\text { environment } \\
\text { al sensitivity }\end{array}$} & \multirow{2}{*}{0.305} & $\begin{array}{l}\text { Ground } \\
\text { elevation }\end{array}$ & 0.67 \\
\hline & & & slope & 0.33 \\
\hline & \multirow{2}{*}{$\begin{array}{l}\text { Vulnerabilit } \\
\text { y of } \\
\text { disaster- } \\
\text { bearing } \\
\text { body } \\
\end{array}$} & \multirow{2}{*}{0.127} & $\begin{array}{l}\text { Average } \\
\text { population }\end{array}$ & 0.83 \\
\hline & & & $\begin{array}{l}\text { GDP per } \\
\text { land }\end{array}$ & 0.17 \\
\hline & $\begin{array}{l}\text { Disaster } \\
\text { prevention } \\
\text { and } \\
\text { mitigation } \\
\text { capabilities }\end{array}$ & 0.079 & $\begin{array}{l}\text { GDP per } \\
\text { capita }\end{array}$ & 1 \\
\hline
\end{tabular}




\section{Result analysis}

\subsection{Hazard risk assessment}

The hazards of hazard factors mainly consider the rainfall intensity and rainfall frequency in Linyi City. The precipitation process takes at least 1 day of continuous precipitation and precipitation greater than $30 \mathrm{~mm}$ as a process, and then the precipitation in the whole process is accumulated as the total precipitation of a heavy rain process. Calculate the daily precipitation data of all stations in Linyi City from 2010 to 2019 during the rainstorm process of $1,2 \ldots 7$ days (including 7 days or more), and establish 7 precipitation process sequences of different time lengths, and use percentages The digit method calculates the precipitation corresponding to $98 \%$, $95 \%, 90 \%, 80 \%$, and $60 \%$ of the precipitation of the 7 time series, and divides the intensity of the rainstorm into five levels: the precipitation is between $60 \%$ and $80 \%$ The floods are level 1 floods, those between $80 \%$ and $90 \%$ are level 2 floods, those between $90 \%$ and $95 \%$ are level 3 floods, those between $95 \%$ and $98 \%$ are level 4 floods, and those between $98 \%$ and $98 \%$ are level 4 floods. It is a level 5 flood. Taking the Yishui County site as an example, the specific values are shown in Table 2 (other sites are omitted). The higher the level of rainfall intensity, the greater the effect on the formation of floods. Five levels of weight are given to rainfall intensity, namely $1 / 15,2 / 15$, $3 / 15,4 / 15$, and $5 / 15$. The weighted comprehensive evaluation method is used to calculate the risk indicators of disaster-causing factors at each site, as shown in Table 3. Spatial interpolation is performed in ArcGIS to obtain a distribution map of the risk levels of flood-causing factors in Linyi City, as shown in Figure 2.

Table 2. Rainfall range of different grades of rainstorm intensity $(\mathrm{R})$ in Yishui County $/ \mathrm{mm}$

\begin{tabular}{|c|c|c|c|c|c|}
\hline Heaven & $\begin{array}{l}\text { First } \\
\text { level }\end{array}$ & $\begin{array}{c}\text { Second } \\
\text { Level }\end{array}$ & $\begin{array}{l}\text { Third } \\
\text { Level }\end{array}$ & $\begin{array}{l}\text { Fourth } \\
\text { Level }\end{array}$ & $\begin{array}{l}\text { Fifth } \\
\text { Level }\end{array}$ \\
\hline 1 & $\begin{array}{c}89 \leq \mathrm{R} \leq 1 \\
56\end{array}$ & $\begin{array}{c}156< \\
R \leq 240\end{array}$ & $\begin{array}{l}240< \\
R \leq 247\end{array}$ & $\begin{array}{l}247< \\
R \leq 507\end{array}$ & $\begin{array}{l}\mathrm{R}> \\
507\end{array}$ \\
\hline 2 & $\begin{array}{c}122 \leq \mathrm{R} \leq \\
213\end{array}$ & $\begin{array}{l}213< \\
R \leq 333\end{array}$ & $\begin{array}{l}333< \\
\mathrm{R} \leq 394\end{array}$ & $\begin{array}{l}394< \\
R \leq 604\end{array}$ & $\begin{array}{l}\mathrm{R}> \\
604 \\
\end{array}$ \\
\hline 3 & $\begin{array}{c}208 \leq \mathrm{R} \leq \\
328\end{array}$ & $\begin{array}{l}328< \\
R \leq 540\end{array}$ & $\begin{array}{l}540< \\
R \leq 835\end{array}$ & $\begin{array}{c}835< \\
\mathrm{R} \leq 109 \\
3\end{array}$ & $\begin{array}{l}\mathrm{R}> \\
1093\end{array}$ \\
\hline 4 & $\begin{array}{c}239 \leq \mathrm{R} \leq \\
328\end{array}$ & $\begin{array}{l}328< \\
R \leq 432\end{array}$ & $\begin{array}{l}432< \\
R \leq 739\end{array}$ & $\begin{array}{l}739< \\
R \leq 923\end{array}$ & $\begin{array}{l}\mathrm{R}> \\
923\end{array}$ \\
\hline 5 & $\begin{array}{c}372 \leq \mathrm{R} \leq \\
754\end{array}$ & $\begin{array}{l}754< \\
\mathrm{R} \leq 819\end{array}$ & $\begin{array}{c}819< \\
\mathrm{R} \leq 854\end{array}$ & $\begin{array}{l}854< \\
R \leq 977\end{array}$ & $\begin{array}{l}\mathrm{R}> \\
977\end{array}$ \\
\hline 6 & $\begin{array}{c}256 \leq \mathrm{R} \leq \\
663\end{array}$ & $\begin{array}{l}663< \\
R \leq 697\end{array}$ & $\begin{array}{l}697< \\
R \leq 901\end{array}$ & $\begin{array}{c}901< \\
\mathrm{R} \leq 122 \\
8\end{array}$ & $\begin{array}{l}\mathrm{R}> \\
1228\end{array}$ \\
\hline 7 & $\begin{array}{c}761 \leq \mathrm{R} \leq \\
1353\end{array}$ & $\begin{array}{l}1353< \\
R \leq 1751\end{array}$ & $\begin{array}{l}1751< \\
\mathrm{R} \leq 1880\end{array}$ & $\begin{array}{c}1880 \\
< \\
\mathrm{R} \leq 262 \\
1 \\
\end{array}$ & $\begin{array}{l}\mathrm{R}> \\
2621\end{array}$ \\
\hline
\end{tabular}

Table 3. Risk indicators of hazard factors at each site in Linyi

\begin{tabular}{|c|c|}
\multicolumn{2}{c}{ City } \\
\hline Site & index \\
\hline Yishui & 13.9 \\
\hline Linyi & 13.4 \\
\hline Cangshan & 13.3 \\
\hline Feixian & 14 \\
\hline Junan & 14.1 \\
\hline Linshu & 13.8 \\
\hline Mengyin & 13.2 \\
\hline Yinan & 13 \\
\hline Pingyi & 12.3 \\
\hline
\end{tabular}

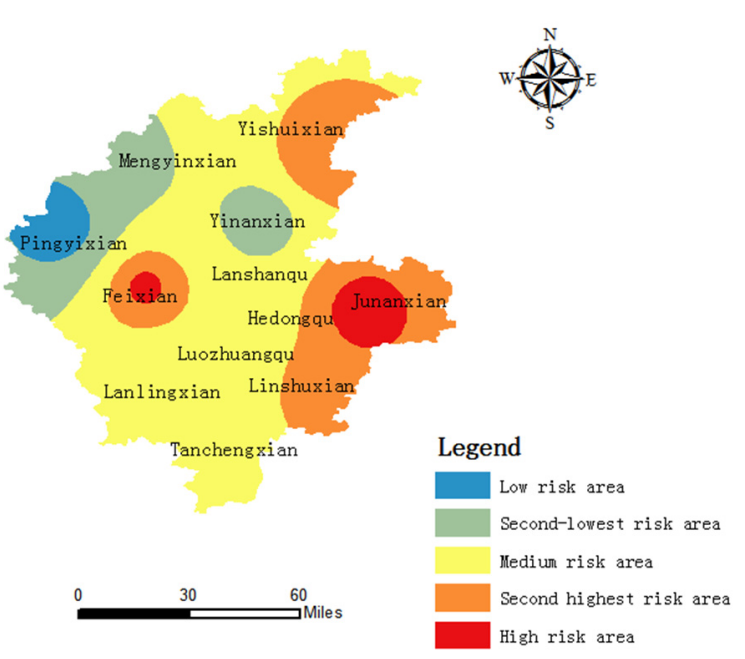

Figure 2. Distribution map of hazard levels of flood-causing factors in Linyi City

\subsection{Environmental Sensitivity Assessment of Disaster Pregnancy}

Disaster-generating environment refers to the natural environment that breeds flood disasters, such as topography, geology, soil, vegetation, water system, etc. The terrain of Linyi City is high in the northwest and low in the southeast. It is mountainous in the north and flat in the middle and south. The topography makes the rainfall in this area greatly affected by the topography, and it is easy to converge from the high terrain to the low terrain. In the case of large areas, long-term rainfall or short-term heavy rainfall is likely to cause water accumulation in mountainous depressions, which is conducive to the formation of floods. In this paper, ground elevation and slope are selected as disaster-pregnant environmental factors. A $30 \mathrm{~m}$ resolution digital elevation model and a $3 \times 3$ rectangular window selected from the grid calculation module of ArcGIS are used to express the relative elevation standard deviation. The lower the elevation, the smaller the standard deviation of elevation, which means that flood disasters are more likely to occur, and the greater the impact value, and the comprehensive impact degree assignment of topographic factors is obtained (Table 4). Analyze the slope and reclassify it. According to the weights given in Table 1, the weighted comprehensive evaluation method is used to obtain the 
disaster-pregnancy environmental sensitivity level distribution map, as shown in Figure 3. The results show that the disaster-pregnancy environmental sensitivity of Linyi City is low in the north and high in the south, and the areas with the strongest sensitivity are mainly Distributed in the south of Tancheng County, Lanshan District, Hedong District, etc., while the north of Yishui County, Mengyin County, etc. are less sensitive. The reason is that the central and southeast parts of Linyi City are low in terrain and the comprehensive influence index of topographic factors is the largest Therefore, it is the most sensitive area for flood disasters.

Table 4. Linyi City Elevation and Elevation Standard Deviation Combination Assignment

\begin{tabular}{|c|c|c|c|}
\hline \multirow{2}{*}{$\begin{array}{c}\text { Terrain } \\
\text { elevation/m }\end{array}$} & \multicolumn{3}{|c|}{ Elevation standard deviation } \\
\cline { 2 - 4 } & $\begin{array}{c}\text { First } \\
\text { level } \\
(\leq 1)\end{array}$ & $\begin{array}{c}\text { Second Level } \\
(1 \sim 10)\end{array}$ & $\begin{array}{c}\text { Third Level } \\
(\geq 10)\end{array}$ \\
\hline $\begin{array}{c}\text { First level } \\
(\leq 100)\end{array}$ & 0.9 & 0.8 & 0.7 \\
\hline $\begin{array}{c}\text { Second Level } \\
(100 \sim \\
300)\end{array}$ & 0.8 & 0.7 & 0.6 \\
\hline $\begin{array}{c}\text { Third Level } \\
(300 \sim \\
700)\end{array}$ & 0.7 & 0.6 & 0.5 \\
\hline $\begin{array}{c}\text { Fourth Level } \\
(\geq 700)\end{array}$ & 0.6 & 0.5 & 0.4 \\
\hline
\end{tabular}

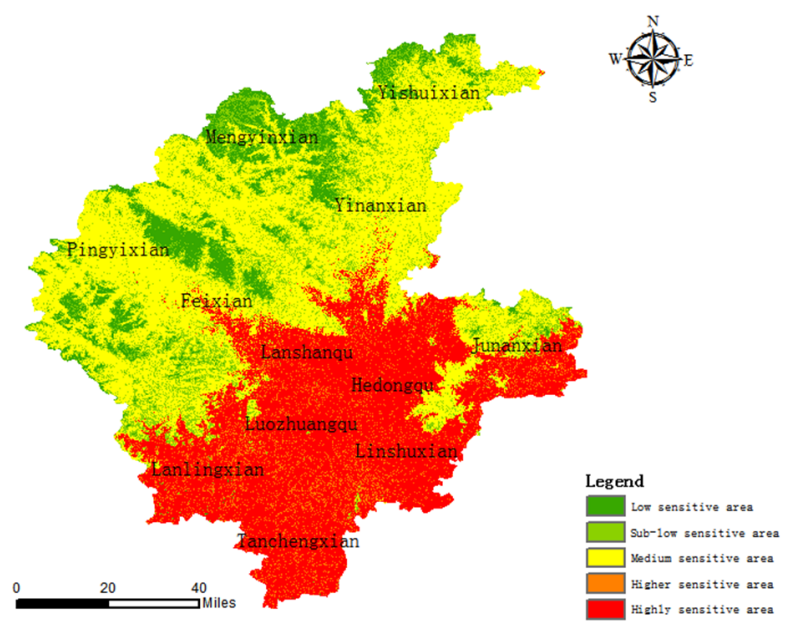

Figure 3. Distribution Map of Environmental Sensitivity Level of Disaster Pregnancy in Linyi City

\subsection{Vulnerability assessment of the carrier}

The occurrence of flood disasters has a certain relationship with the carriers of disasters. The losses caused by disasters generally depend on the economic conditions and population density of the disaster-affected areas. The economy is developed, and the densely populated places suffer from flood disasters. This article selects the average GDP and the average population in Linyi City in 2019 as the risk assessment indicators. After the data is standardized, the index values are assigned weights according to Table 1, and the weighted comprehensive evaluation method is used to obtain the vulnerability distribution of the carrier. Figure, see Figure 4. It can be seen from the figure that Lanshan District has the densest population and developed economic level and is prone to disasters, followed by Yishui County and Lanling County. Mengyin County and Linshu County have lower population density and have the lowest vulnerability in the city.

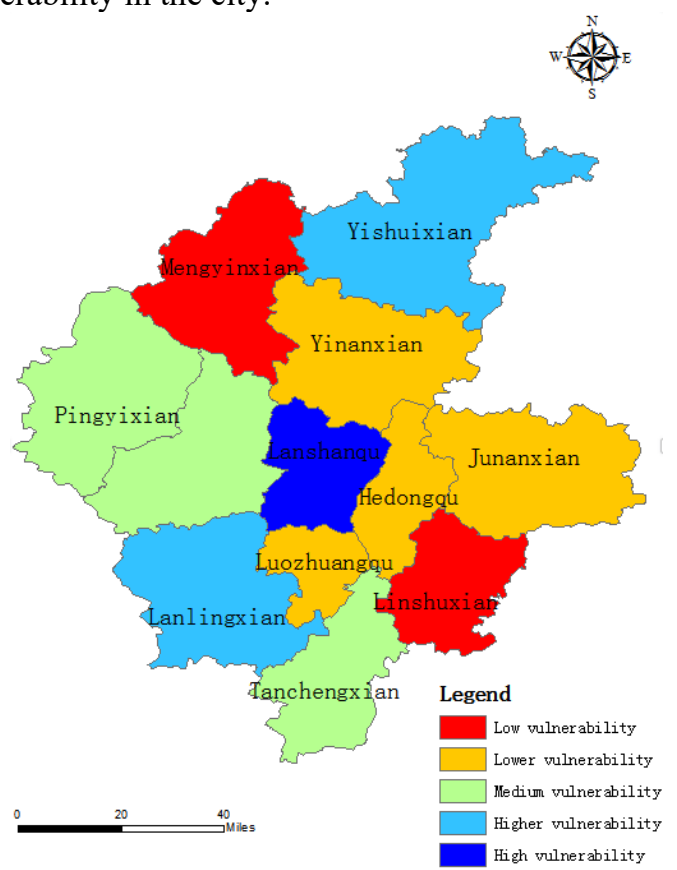

Figure 4. Distribution map of vulnerability levels of flood bearing bodies in Linyi City

\subsection{Disaster prevention and mitigation capability assessment}

According to the "Linyi City Statistical Illustrations in 2019", per capita GDP is selected as the evaluation index of disaster prevention and mitigation ability and standardized processing. It is divided into 5 grades on the ArcGIS platform to obtain the distribution map of Linyi City's flood prevention and disaster mitigation ability level, as shown in Figure 5. Comprehensive analysis shows that Linyi's central urban area has strong disaster prevention and mitigation capabilities, while Junan and Mengyin counties have weaker disaster prevention capabilities.

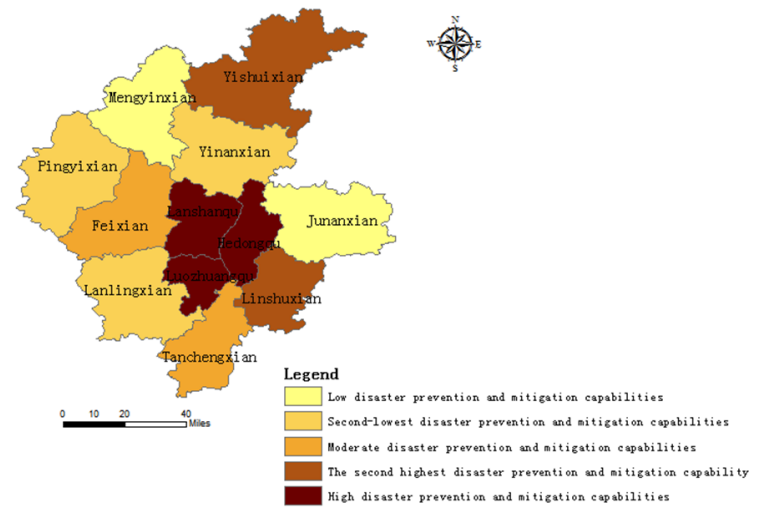

Figure 5. Distribution map of Linyi City's flood and waterlogging disaster prevention and mitigation capabilities 


\section{Conclusion}

This paper builds a flood disaster risk assessment index system, comprehensively considers precipitation, topography, population density, GDP and other information, and uses GIS technology to assess the flood disaster risk in Linyi City, which can more objectively reflect the flood disaster risk in different regions. reality. However, there are still a series of problems such as incomplete basic information, disaster mechanism analysis and assessment techniques need to be strengthened. Therefore, in the future, the breadth and depth of risk assessment will be expanded to provide better support for risk assessment.

\section{References}

1. Chen, H., Chen, G., Ding, G. (2003) Risk assessment of regional flood disaster based on GIS. Yangtze River., 06: 49.

2. Zhao, W., Huang, J., Zhang, Z. (2017) Research on Comprehensive Risk Assessment of Flood Disaster in Chongqing City Based on GIS. Journal of Southwest China Normal University(Natural Science Edition)., 42(02): 34-42.

3. Li, C., Tian, J., Shen, R. (2020) Research progress of flood disaster risk assessment. Journal of Catastrophology., 35(03): 131-136.

4. Cheng, L., Fu, M., Wang, L. (2019) Risk Assessment of Flood Disaster at County Level Based on RS and GIS. South-to-North Water Transfers and Water Science \& Technology., 17(06): 37-44+68.
5. Chen, W., Wang, X., Deng, S. (2019) Integrated urban flood vulnerability assessment using local spatial dependence-based probabilistic approach. Journal of Hydrology., 575: 454-469.

6. Li, S. (2019) Risk Assessment and Zoning of Rainstorm and Flood Disasters in Southeastern Inner Mongolia: A Case Study of Tongliao City. Meteorology Journal of Inner Mongolia., 01: 23-28.

7. Xue, X., Ma, J., Li, H. (2012) Gis-based risk assessment and regionalization of township flood disaster: a case study in Linzi District, Zibo, Shandong province. Journal of Catastrophology., 27(04): 71-74+79.

8. Zhu, Z., Zhang, Y. (2021) Flood disaster risk assessment based on random forest algorithm. Neural Computing and Applications., : 1-13.

9. Huang, G., Luo, H., Lu, X. (2020) Summary of urban flood disaster risk analysis and zoning methods. Water Resources Protection., 36(06): 1-6+17.

10. Wu, S., Zhao, W., Wang, Z. (2020) GIS-based flood disaster risk assessment and zoning: Taking Zhejiang Province as an example. China Rural Water and Hydropower., (06): 51-57.

11. Camarasa-Belmonte A. M., Soriano-García J. (2012) Flood risk assessment and mapping in peri-urban Mediterranean environments using hydrogeomorphology. Application to ephemeral streams in the Valencia region (eastern Spain). Landscape and Urban Planning., 104(2): 189-200. 